\title{
Letters as Portraits of Intimacy in Literature Studies
}

\author{
Monica Mastrantonio \\ Department of English and Related Literature, University of York, York, UK \\ Email: monica.mastrantonio@york.ac.uk
}

How to cite this paper: Mastrantonio, M. (2021). Letters as Portraits of Intimacy in Literature Studies. Advances in Literary Study, 9, 230-238.

https://doi.org/10.4236/als.2021.94024

Received: August 26, 2021

Accepted: October 26, 2021

Published: October 29, 2021

Copyright (C) 2021 by author(s) and Scientific Research Publishing Inc. This work is licensed under the Creative Commons Attribution International License (CC BY 4.0).

http://creativecommons.org/licenses/by/4.0/

(c) (i) Open Access

\begin{abstract}
Letters are not merely literature pieces for curiosity and daily amenities, but means of extensive use in the past when there were not many options for distance communication. Although privately written letters are public documents that offer valuable information to understand human relations not only in the past, in the present and future. Letters can be used in multiple fields of knowledge and disciplines, and offer extensive possibilities for interdisciplinarity. Bergson's concept of knowing includes intuitive knowledge and temporal multiplicities. In this context, the past is made present when common aspects and empathy are evidenced. Therefore, much of the content of these letters are similar to issues that are common in today's societies. The method of reading and using them interactively and empathically is called organic. Thus, past, present, and future are not in a linear sequence but juxtaposed. The three authors whose letters are presented and discussed to showcase the above are, Lord Byron to his editor, the letters from Lady Mary Wortley Montagu to her former husband, the letters from Emily Dickson to her tutor. By using Bergson's concepts of time and intuition-the dilemmas of relating to a publisher, to an ex-husband, and a tutor display how intimacy can play an important role in creating bonds across time and space in these masters of literature.
\end{abstract}

\section{Keywords}

Methods, Letters, Literature, Language, Organic

\section{Introduction}

"A Letter always feels to me like immortality because it is the mind alone without corporeal friend. Indebted in our talk to attitude and accent, there seems a spectral power in thought that walks alone-I would like to thank you for your 
great kindness but never try to lift the words which I cannot hold," Emily Dickson.

There are many formats of written texts-articles, essays, poems, letters, diaries, and the list could go on. These are not merely objects of literature, but interactive ways to create and boost communication among individuals (Barton \& Hall, 2000).

Letters are frequently used in humanities research as an amendment, a curiosity, a document, a source of data towards a situation or fact. They may highlight autobiographical and historical data, and are one of the richest data towards women's voices in the fields of literature, politics, and science (Richter, 2010).

Letters link the private and public dimensions together with mobility-they had to cross borders and many other hardships to arrive at their destiny (Franklin, 2020).

Letters will be used in this research in their multi-dimensional aspect. They connect past, present, and may add new views towards the future. They bring intimacy in evidence-they are moving texts. They have a historical aspect, but as living history, they can be brought into life again.

Letters do not only present personal annotations and frugality about everyday living, but they transform experiences. Letters date back from $500 \mathrm{BC}$ with the first recorded handwritten letter by Persian Queen Atossa, according to the ancient historian Hellanicus. The leaves of plants allowed the possibility of having messages written on them and being delivered to their destiny. In the Bible, for instance, most of the New Testament are letters from St. Paul (see Journal for the Study of Paul and His Letters by Penn State University Press).

By the 18th century, letter writing was predominant, in such a way, that one of the first prose narratives from Samuel Richardson's called "Pamela", and it was composed entirely of letters of a daughter to her parents (Derek Taylor, 2018).

Most of the letter-authors knew they would be read in the future, mentioning this like a graduate of Jefferson Medical College in 1841, John Plimpton Green, who addresses to those who will read this in the future (Dunster et al., 2014).

Last century, “A Soldier's Last Letter”, "Please, Mr. Postman”, "I’m Gonna Sit Right Down and Write Myself a Letter", to name a few, have maintained the old habit alive.

Correspondences among writers, lovers, public figures, and friends were the only possible way for distant people to communicate (Dyer, 2020; Newton, 2020).

Nevertheless, letters are narratives, language in action, production of texts and contexts. It is important to recognize that these texts bring language in movement and give life to them (Curran, 2018).

They are objects of love and hate (Gori, 2011), of possession, travels, perils and adventures, of good and bad news, letters constitute actions and produce effects, mobilize manifestations, declare war, or even inspire others. On top of all that, letters bring authors into ink and paper (Vinci-Booher et al., 2019). 


\section{Bergson and the "Intuitive" Method}

The aim of this study is to highlight the importance of letter studies and to use three examples to showcase how letters can be used in interdisciplinary studies. The method used in this research is named "organic" upon Bergson's intuitive method (Fell, 2012). This method of reading letters compounds a system that is multi-dimensional and expansive by creating multiple interactions between past, present, and future making it possible to have multiple perspectives upon past letters.

What is being looked at are not the differences between the present and the past, but what links and connects both-intimacy as the possibility of being empathic. Nevertheless, it is not knowledge that connects present and past, but feelings that connect us to them. Although intuition and intellect are separate skills in our civilization, by reading them organically, it is possible to reunite them.

The letters showcased here present how their topics seem actual, and intuition and sympathy connect us to them.

In Time and Free Will, Bergson (1910) deals with the self as a totality of two components: 1) One is the superficial self that is limited by the conceptual language, habits, and rules of the society (social side). 2) However, another is the fundamental self that transcends the structures of social life and enables us to be aware of the reality of dynamic life (conscious life). This free side moves us away from the domination of social life towards the inner free life. A life that may lead to continuity and that puts us in dialogue with these authors from the past (Westmoreland \& Karas, 2016).

Bergson's notion of intuition as a concept and method is applied as a way to create knowledge, and this preposition has not been deeply explored in research. Intuition is a non-intellectual way of knowing reality. For (Bergson, 1946), intuition is the way that enables us to attain absolute reality to understand the whole of things and ourselves.

His particular method does not take only historical aspects, linguistic ones, metrics, relationships among authors, but how these contents have lasted so far. This means their content is actual.

All three authors made use of letter writing extensively and with multiple purposes (VanHaitsma, 2014) following intuition; this research takes an independent front-line. This way, we grasp the knowledge of the object in itself by experiencing it (Olkowski, 2020). This allows us to follow through with change, evolution, and movement of the object from the inside.

These letters were randomly selected, but in all of them, there are feelings being fully expressed. These authors were all extensive letter-writers. Thus, they were selected because they deeply expressed themselves in letters. Besides that, these letters bring an in-depth perspective of the actual world. They bring topics that can be easily found around nowadays although they were from hundreds ago. The more they are read, the more sympathy can be built towards those let- 
ters. We can feel what they felt. It is possible to feel wholly with them, to share their humanity-similar feelings, issues, voices are also mine, paving the way to attain absolute knowledge. In short, the experience of sympathy requires going into an object and grasping its uniqueness and peculiarity.

Analysis operates on immobility, while intuition is located in mobility, in other words, in duration. For (Bergson, 1910, 1946) instinct and sympathy are not feelings, these are ways of knowing each other. This transport of intuition-sympathy is not ordinary language or simple verbal communication, but, in the sense of the French expression "transports amoureux," something to express the inexpressible. This is what is highlighted here. I have felt many times like Lord Byron (Byron, 2011, 2015) having issues with editors, I have felt like (Halsband, 1965, 1967), and there are times that I think I was just like Emily Dickson in search of approval of my tutor.

Time is consequently a "multiplicité indistinct or qualitative", not broken by spatial intervals, but in juxtaposition. Everything is given all at once ("tout d'un coup"), but time is what prevents everything from being present. In space, there is no real succession, but simultaneity and juxtaposition.

Duration is the continuous progress of the past that gets into the future and which swells as it advances. Thus, our immediate conscious states are formed by spatial multiplicity.

In the "organic" approach to letter reading of letters from the past, this research studied these letters in search of juxtaposition and unicity, of what is unique and eternal in them.

\section{The Letters from Dickson, Byron, and Lady Montagu}

The letters chosen in this study are all from the 17th and 18th century period. By reading them, readers are directly put into contact with the intimacy and struggles of their authors. They show us their inspirations, doubts, fragilities. The reason letters are such grand ways to bring the past into life. The authors' voices are there- a voice that was addressed to someone specifically in the past, but at the same time, it is the voice of the self that demonstrates intimacy.

Looking back at them, these voices have been pulled out, they seem to remain suspended in the air, but when we read and make sense of them. The result is empathy towards their authors as if we had pulled a balloon and were hold it close to us now. They show our humanities, not our intellect (Dickson, 1869; Byron, 2015; Halsband, 1965).

\subsection{Letter from Emily Dickinson to Higginson}

\section{“25 April 1862}

Mr. Higginson,

Your kindness claimed earlier gratitude-but I was ill-and write today, from my pillow.

Thank you for the surgery - it was not so painful as I supposed. I bring you 
others-as you ask-though they might not differ-

While my thought is undressed-I can make the distinction, but when I put them in the Gown - they look alike, and numb.

You asked how old I was? I made no verse-but one or two-until this winter Sir-

I had a terror-since September-I could tell to none-and so I sing, as the Boy does by the Burying Ground-because I am afraid- You inquire my Books-For Poets-I have Keats-and Mr and Mrs Browning. For Prose-Mr Ruskin-Sir Thomas Browne-and the Revelations. I went to school-but in your manner of the phrase-had no education. When a little Girl, I had a friend, who taught me Immortality-but venturing too near, himself-he never returned-Soon after, my Tutor, died - and for several years, my Lexicon - was my only companion-Then I found one more-but he was not contented I be his scholar-so he left the Land.

You ask of my Companions Hills-Sir-and the Sundown-and a Dog-large as myself, that my Father bought me-They are better than Beings-because they know-but do not tell-and the noise in the Pool, at Noon - excels my Piano. I have a Brother and Sister - My Mother does not care for thought-and Father, too busy with his Briefs - to notice what we do - He buys me many Books - but begs me not to read them-because he fears they joggle the Mind. They are religious-except me-and address an Eclipse, every morning-whom they call their "Father." But I fear my story fatigues you-I would like to learn-Could you tell me how to grow-or is it unconveyed- like Melody-or Witchcraft?

You speak of Mr Whitman-I never read his Book-but was told that he was disgraceful-

I read Miss Prescott's "Circumstance," but it followed me, in the Dark-so I avoided her-

Journals came to my Father's House, this winter- and asked me for my Mind-and when I asked them "Why," they said I was penurious - and they, would use it for the World -

I could not weigh myself-Myself-

My size felt small- to me- I read your Chapters in the Atlantic- and experienced honour for you-I was sure you would not reject a confiding question-

Is this- Sir-what you asked me to tell you?

Your friend,

E. Dickinson.”

\subsection{Letter from Lord Byron to John Murray}

"Stilton, Oct. 3, 1813.

Dear Sir,-I have just recollected an alteration you may make in the proof to be sent to Aston.-Among the lines on Hassan's Serai, not far from the beginning, is this:

Unmeet for Solitude to share.

Now to share implies more than one, and Solitude is a single person; it must be thus: 
For many a gilded chamber's there,

Which Solitude might well forbear;

and so on.-My address is Aston Hall, Rotherham. Will you adopt this correction? and pray accept a cheese from me for your trouble.

Ever yours,

B.

P. S.-I leave this to your discretion; if anybody thinks the old line a good one or the cheese a bad one, don't accept either. But, in that case, the word share is repeated soon after in the line:

To share the Master's "bread and salt;"

and must be altered to:

To break the Master's bread and salt.

This is not so well, though-confound it! If the old line stands, let the other run thus:

Nor there will weary traveller halt,

To bless the sacred "bread and salt."

Note.-To partake of food-to break bread and taste salt with your host-ensures the safety of the guest; even though an enemy, his person from that moment becomes sacred."

\subsection{Letter from Lady Mary Montagu to Mr. Wortley}

“To Wortley [28 April 1711]

I cannot write and only say I have receiv'd yours; I have allwaies ten thousand things to say to you, and yet I solemnly and sincerely desire you to desist writeing. I could wish it was possible to keep a Correspondance with you without scandal or discovery, but as that cannot be, in Generosity do not make me uneasy. There is nothing I would not do to make you easy. That Gentleman has no interest in my heart, and yet I think he has as much as he deserves. I have the vanity to beleive a Man that could engage me must have a greater share of understanding. Had he desir'd it, it could never have been, but tis no Lie to assure you, he never attempted it. Mr. D. is one of those fine people [that] have the same way of talking to all the Women they see, that everybody suffers and nobody esteems. I cannot deny he has often entertaind me in that manner he does a thousand others, which I never took to be in earnest because I knew he never meant it so. I beleive he may have been well with some women, but I hope they have been women of a character very different to mine. All I know is that there was never anything between us but a little raillery. I suppose it will [be] no hard matter for you to believe this. I wish I could as easily clear my selfe from the other. My word is not sufficient for that, in your Opinion. Time and observation would soon do it, but then you may imagine me forsaken, or that we are broke off from some other cause, but it will be impossible to convince you of the truth.

I have seen enough of the world not to be very fond of it. I have seen so many Acquaintance unhappy, and heard so many secret complaints of Husbands, I have often resolved never to marry, and allwaies not to Sacrifice my selfe to an 
Estate. Having done with your Heart, I have no pretensions to yours. As I am, I enjoy every satisfaction but your Conversation. Marrying you is part with every other for that; I once resolved to do it shows set no common value on it. While I thought you loved me, I could have liv'd with you in any place or Circumstances. I have but this satisfaction, that one time or other, I am assur'd, you will think of me and regret you have wrong'd me. Adeiu. I desire you not to answer.

Address To Mr Edward Wortley Mountague [in another hand] at Wortly near Sheffeild Yorkshire Free."

\section{Discussion}

The three letters of this research were written and assembled by different authors at different places and situations-they all write about different aspects of their lives and circumstances. However, when the letters are read taking into account Bergson's method of intuition, sympathy, and multiplicity of times-the interaction with them brings new aspects into analysis. The categories used to analyze the data are empathy, time, and place.

\subsection{Empathy}

When the reading material is read intuitively, it is possible to share the same perspective as the author; it is possible to be one with them. It is possible to experience the juxtaposition of the other within oneself. The researcher becomes one with the author of the letters and they create change upon us. It is possible to infer, for instance, that Emily Dickson was quite lonely most of her time. It is also possible to infer that Lord Byron and Mr. Murray had many changes in the written versions of the texts-he even sends him a piece of cheese and makes a parody with the sharing of the perils and glories between the editor and author. Lady Mary Montagu has resigned herself in trying to convince her ex-husband. There has been too much talk about them and what goes around. She truly says that she has been to the world and seen it a lot, and about her, other flirts and interest, but she mentions her affection for her and that one day he will be able to see her as she is.

\subsection{Time}

Time, although written more than two centuries ago, the preserved letters can immediately create a bond with the present and the future. La duree-the duration of time is not connected to the chronological calendar, but by bridges that are created in completion to a big picture. Time is not the linear chronological time that disconnects us from them, here, in time as experience, all the time-gap, which separates these letters from the actual time, means nothing. Here, the three hundred years which separate their past and 2021 does not matter at all when the perspective is the same-humans have been to these places somehow...they have felt lonely, they have given away too much cheese, and they have been expecting for some sort of recognition. This is humanity. 


\subsection{Place}

Place-these letters have been written from different places, but they all carry inside them the art of letter writing. Someone who was writing a letter for the first time has not written them, but by authors, whose letters gained international recognition. This recognition is also located in the places they have been, which lead to notoriety and fame, and because they wrote letters like they knew they would be read and important in the future-mentioning this in them. A letter is a place where two people meet.

\section{Discussion}

The use of letters in research, the habit of writing and reading letters, the reading of past letters, and the use of letters from the past are very useful in literature studies. Personal letters can serve as an important role in the construction of historical narratives, but they can also teach us not only about the past, but also about ourselves, they can highlight humanity and empathy.

To move further in the use of letters in literature studies, the use of Bergson's concept of time as La duree, and the "organic" method of reading letters as a place can help us to create larger connections with them, and attain what is permanent in humanity. As it is stated in the letters presents here, Emily's relationship with her tutor and her loneliness, Lord Byron struggles with his editor, Lady Montagu's affection for her ex-husband showcase feelings that are common to these days.

Alternatively, paraphrasing Curran (2018) "When we keep letters, they continue their work" - when we read them, we bring their lives back.

\section{Conflicts of Interest}

The author declares no conflicts of interest regarding the publication of this paper.

\section{References}

Barton, D., \& Hall, N. (2000). Letter Writing as a Social Practice (Studies in Written Language and Literacy). John Benjamins Publishing Company. https://doi.org/10.1075/swll.9

Bergson, H. (1910). Time and Free Will, an Essay on the Immediate Data of Consciousness. S. Sonnenschein \& Co.

Bergson, H. (1946). The Creative Mind. Philosophical Library.

Byron, L. (2011). The Works of Lord Byron: Letters and Journals (Vol. 2). Project Gutenberg.

Byron, L. (2015). The Works of Lord Byron: Letters and Journals (Vol. 1). Project Gutenberg. https://www.gutenberg.org/files/8901/8901-h/8901-h.htm

Curran, L. (2018, June 21). Letters, Letter Writing, and Epistolary Novels. British Library. https://www.bl.uk/restoration-18th-century-literature/articles/letters-letter-writing-an d-epistolary-novels

Derek Taylor, E. (2018). Louise Curran. Samuel Richardson and the Art of Letter-Writing. 
The Review of English Studies, 69, 383-385. https://doi.org/10.1093/res/hgx076

Dickson, E. (1869). Letters from Dickinson to Higginson. Letters, Dickinson Electronic Archives. http://archive.emilydickinson.org/correspondence/higginson/1330.html

Dunster, E., Kipnis, D. G., \& Michael Angelo, F. (2014). Transcribing and Digitizing Eighteenth and Nineteenth-Century Letters for a Historical Digital. Medical Reference Services Quarterly, 33, 278-282. https://doi.org/10.1080/02763869.2014.925671

Dyer, G. (2020). Lord Byron's Trademark. ELH, 87, 679-705. https://doi.org/10.1353/elh.2020.0024

Fell, E. (2012). Duration, Temporality, Self-Prospects for the Future of Bergsonism. Peter Lang Verlag.

Franklin, C. (2020). The Rhetoric of Letter-Keeping. Peitho, 22.

Gori, C. (2011). Women and the World of Knowledge. Four Collections of Love Let ters in Nineteenth-Century Italy. Women's History Review, 20, 641-650. https://doi.org/10.1080/09612025.2011.599624

Halsband, R. (ed.) (1965). The Complete Letters of Lady Mary Wortley Montagu, Vol. 1: 1708-1720. Oxford University Press.

Halsband, R. (ed.) (1967). The Complete Letters of Lady Mary Wortley Montagu, Vol. 3: 1752-1762. Oxford University Press.

Newton, E. (2020, March). A Note from the Library: Florence Nightingale through Letters. Blog.

Olkowski, D. (2010). In Search of Lost Time: Merleau-Ponty, Bergson, and the Time of Objects. Continental Philosophy Review, 43, 525-544. https://doi.org/10.1007/s11007-010-9152-7

Richter, N. L. (2010). Female Writers in the 18th Century: The Power of Imagination. Quiries Journal/Student Pulse, 2, 1 p. http://www.inquiriesjournal.com/a?id=301

VanHaitsma, P. (2014) Queering the Language of the Heart. Romantic Letters, Genre Instruction, and Rhetorical Practice. Rhetoric Society Quarterly, 44, 6-24. https://doi.org/10.1080/02773945.2013.861009

Vinci-Booher, S., Hu, C., \& James, K. (2019). An Analysis of the Brain Systems Involved with Producing Letters by Hand. Journal of Cognitive Neuroscience, 31, 138-154. https://doi.org/10.1162/jocn_a_01340

Westmoreland, W., \& Karas, B. (2016). Bergson(-ism) Remembered. Journal of French and Francophone Philosophy-Revue de la philosophie française et de langue française, 24, 221-258. https://www.jffp.org https://doi.org/10.5195/jffp.2016.778 